\title{
The antimicrobial activity of essential oils and extraction of medicinal plants; use as adjuvant therapy in the treatment of cancer of the lymphatic system
}

\author{
Dragan Jovanov* \\ Environmental Resources and Food Security Management, Mit Universsity-Skopje, Macedonia
}

\begin{abstract} examination are conducted survey of 150 people. antimicrobial activity in their use depending on the used concentration of essential oil.

\section{Introduction}

Essential oils derived from plants or their secondary metabolism, which are formed by a group of cells or fibers placed in stems and leaves of plants. Essential oils are isolated with plant material by via several methods, of which the most widely used method of distillation. These oils represent a mixture of terpenoids as the main component, and specific monoperteni sekviperteni although not excluded the presence of diterpenes. Essential oils may be characterized based on the presence of their main components. The discovery and exploration of essential oils constitute the subject of much research for many scientists and researchers [1-9].
\end{abstract}

The goal of research in this paper is to determine the antimicrobial activity of essential oils from plants: Galium verum, Echinacea, Garlic, Turmeric, Corn silk, Raspberry, Red John's wort St. John's Wort and Ginger and their use as adjuvant therapy in the treatment of cancer the lymphatic system. Antibacterial activity and

Studies on antimicrobial activity of essential oils extracted from plants and their use in the treatment of cancer of the lymphatic system were examined 3 years.

Essential oils from plants Galium verum, Echinacea, Garlic, Turmeric, Corn silk, Raspberry, Red John's wort St. John's Wort and Ginger manifested different

\section{The experimental part and method of operation}

The achievement of the aforementioned objectives in this study, were been researched with these herbs and their essential oils as adjuvant treatments in the treatment of cancer of the lymphatic system of 150 respondents aged 20 years, 20-40 years and respondents over 60 years (Table 1):

$$
\begin{aligned}
& \text { - Galium verum Echinacea } \\
& \text { - Garlic, Turmeric, } \\
& \text { - Corn silk, Raspberry, } \\
& \text { - Red John's wort St. John's Wort } \\
& \text { - Ginger }
\end{aligned}
$$

\section{Results and discussion}

Does the correct use of galium verum, echinacea, garlic, turmeric, corn silk, raspberry, red john's wort st. john's wort and ginger have achieved the expected results?

Of the total number of respondents, we find that with proper use of Galium verum, Echinacea, Garlic, Turmeric, Corn silk, Raspberry, Red
John's wort St. John's Wort and Ginger, 71.3 persons have achieved the expected results. Whereas $20.7 \%$ of respondents partly achieved the expected results. $8 \%$ of respondents did not achieved the expected results in the proper use of Galium verum, Echinacea, Garlic, Turmeric, Corn silk, Raspberry, Red John's wort St. John's Wort and Ginger in order to improve health status in cancer (Table 2).

On the classification of respondents male and female, in this matter in both sexes in the proper use of Galium verum, Echinacea, Garlic, Turmeric, Corn silk, Raspberry, Red John's wort St. John's Wort and Ginger have achieved the expected results. And while in both cases also, there are volunteers with proper use showed a partial effect or no effect.

\section{Table 1. Respondents statistics}

Total number of respondents: 150

\begin{tabular}{|c|c|c|c|c|c|}
\hline Men & Women & To 20 years & From 20-40 years & From 40-60 years & Over 60 years \\
\hline 67 & 83 & 22 & 45 & 56 & 27 \\
\hline $44.7 \%$ & $55.3 \%$ & $14.7 \%$ & $30 \%$ & $37.3 \%$ & $18 \%$ \\
\hline
\end{tabular}

Table 2. Response towards the correct use of galium verum, echinacea, garlic, turmeric, corn silk, raspberry, red john's wort st. john's wort and ginger

\begin{tabular}{|c|c|c|c|}
\hline & Yes & No & Partially \\
\hline Men & 46 & 6 & 15 \\
\hline Women & 61 & 6 & 16 \\
\hline$\%$ & $71.3 \%$ & $8 \%$ & $20.7 \%$ \\
\hline
\end{tabular}

Correspondence to: Dragan Jovanov, $\mathrm{PhD}$, Environmental Resources and Food Security Management, Mit Universsity-Skopje, Macedonia, Tel: 38970867356; E-mail: daci.j@hotmail.com

Key words: essential oils, Galium verum, lymphatic system, antimicrobial activity, treatment, raspberry, echinacea

Received: June 02, 2017; Accepted: July 01, 2017; Published: July 04, 2017 

system

In the classification of respondents by age, we can conclude that among those 40 to 60 years reported that they had achieved positive results with these medicinal plants. Among subjects 20 to 40 years has the highest number of persons who reported that they had achieved partial results in the proper use of Galium verum, Echinacea, Garlic, Turmeric, Corn silk, Raspberry, Red John's wort St. John's Wort and Ginger, in addition to most of them that They said they fully achieved the expected results. Most people over 60 years have achieved the expected results, but some of them answered partly not. Whereas, among those 20 years and over 60 years in common is that the same number of respondents reported that they have achieved the expected results in the proper use of these medicinal plants.

Have you had any allergic reactions or side effects in using some of these plants in addition to the treatment of cancer of the lymphatic system?

When it comes to allergic reactions to these medicinal plants, the total number of respondents $76.7 \%$ said they did not experience allergic reactions. Only $8.6 \%$ of respondents appeared partial allergic reactions. And $14.7 \%$ of respondents said that the use of these medicinal plants had symptoms of allergy.

In male and female respondents the percentage of those who failed allergic reactions is same.The percentage of women who did not appear any allergic reactions is increasing, while males notice small number of persons who appeared partly allergic symptoms (Table 3 ).

In the second question, the number of respondents we can see that in people 40-60 years is the highest percentage of allergic reactions. Most of the respondents those up to 20 years, between 20- 40 and people over 60 years did not show an allergic reaction to the use of these medicinal plants, so their rates are roughly the same.

A relative of full and partial allergic reactions in people between 20-40 years is the highest percentage of partial allergic reaction to these medicinal plants.

Are you aware that some of these plants are contraindicated for use with certain medications to treat chronic conditions (pressure, heart disease, etc.)?

In the context of information among respondents that these medicinal plants are contraindicated for use in treating chronic diseases, most of the respondents $44 \%$ said they are informed in this regard. Not informed $34 \%$ and partially informed $22 \%$ of respondents. In female level of information is greater, compared to males (Table 4).

Among persons between 40 to 60 years is equal to the number of people who are informed and who are not informed about kontraindikacionite effects from taking Galium verum, Echinacea, Garlic, Turmeric, Corn silk, Raspberry, Red John's wort St. John's Wort and Ginger in chronic diseases. People over 60 years of age have the lowest percentage of partial information on the matter. And people over 20 years have the lowest percentage of full awareness kontraindikacionite effects (Table 5).

Would you rather prefer to undergo vocational educated persons (herbalists) or lack of professional competence that claim to have experience in the application of herbal preparations and herbal remedies?

Of the total number of pupils of the tenth question, 99\% said they want education to implement vocational educational entities (phytotherapeutists), and only one percent of respondents said that
Table 3. Response towards allergic reactions

\begin{tabular}{|c|c|c|c|}
\hline & Yes & No & Partially \\
\hline To 20 years & 15 & 1 & 6 \\
\hline From 20-40 years & 28 & 4 & 13 \\
\hline From 40-60 years & 42 & 6 & 8 \\
\hline Over 60 years & 22 & 1 & 4 \\
\hline$\%$ & $71.3 \%$ & $8 \%$ & $20.7 \%$ \\
\hline
\end{tabular}

Table 4. Response towards chronic conditions

\begin{tabular}{|c|c|c|c|}
\hline & Yes & No & Partially \\
\hline Men & 11 & 51 & 5 \\
\hline Women & 11 & 64 & 8 \\
\hline$\%$ & $14.7 \%$ & $76.7 \%$ & $8.6 \%$ \\
\hline
\end{tabular}

Table 5. Response towards kontraindikacionite effects

\begin{tabular}{|c|c|c|c|}
\hline & Yes & No & Partially \\
\hline To 20 years & 2 & 18 & 2 \\
\hline From 20-40 years & 6 & 35 & 4 \\
\hline From 40-60 years & 12 & 38 & 6 \\
\hline Over 60 years & 3 & 22 & 2 \\
\hline$\%$ & $14.7 \%$ & $76.7 \%$ & $8.6 \%$ \\
\hline
\end{tabular}

Table 6. Response towards opting herbalists

\begin{tabular}{|c|c|c|}
\hline & Vocational education & Vocational education and training \\
\hline Men & 67 & 0 \\
\hline Women & 82 & 1 \\
\hline$\%$ & $99 \%$ & $1 \%$ \\
\hline
\end{tabular}

additional education can be carried out and an incompetent person / person without expert education (Table 6).

\section{Conclusion}

From the survey of this paper, we come to the conclusion that in Macedonia almost all of citizens are informed with Galium verum, Echinacea, Garlic, Turmeric, Corn silk, Raspberry, Red John's wort St. John's Wort and Ginger and their health benefits. Also, we can conclude that the majority of respondents through the antimicrobial activity of these medicinal plants achieved the expected results. Most of the respondents are aware of the side effects under certain conditions, such as allergic reactions, pregnancy, some autoimmune diseases and others. We conclude that the respondents said that detailed information on the use, application, correct dosages, contraindications and side effects.

From the total number of respondents (male/female) in respect of all age limits have said that education would like to receive the professional, competent people who in their view are better suited to do the same.

This paper develops a really interesting and necessary subject for human health, that the whole despite a theoretical and practical application.

\section{References}

1. Azzouz MA (1982) Comparative antimycotic effects of selected herb, species, plant components and commercial antifungal agents. J Food Prot 45: 1298-1301.

2. Крушан Ф (1956) Лјековито и сродно биље, Загреб.

3. Гаммерман АФ (1967) Курс фармакогнозија, Москва.

4. Туцаков J (1971) Лечење биљем, Београд.

5. Туцаков J (1964) Фармакогнозија, Београд. 
Jovanov D (2017) The antimicrobial activity of essential oils and extraction of medicinal plants; use as adjuvant therapy in the treatment of cancer of the lymphatic system

6. Јованов Д (2013) Лечење со природни лековити билки (билни рецепти).

7. Јованов Д (2013) Нутриционизам, лековити растенија, спорт и здрав живот.
8. Јованов Д (2013) Лековити ароматични растенија.

9. Јованов Д, Јованова М (2013) Лековити зачински растенија.

Copyright: (2017 Jovanov D. This is an open-access article distributed under the terms of the Creative Commons Attribution License, which permits unrestricted use, distribution, and reproduction in any medium, provided the original author and source are credited. 